Vol. 3, No. 2, 2016

UDC 338.5:336.225

A. Yasinska

$\mathrm{PhD}$ in Economics, Associate Professor

Lviv Polytechnic National University

\title{
LAW AND STATUTORY REGULATION OF TRANSFER PRICE FORMATION IN UKRAINE
}

\begin{abstract}
The paper outlines the methods of transfer price formation and their law and statutory regulation in Ukraine, considers peculiarities of methods and lists main advantages and disadvantages of practical application of transfer price formation methods in Ukraine on the basis of the amendments introduced into the legislation.
\end{abstract}

Key words: transfer price formation, estimation methods, controlled transactions, related persons.

Formulation of the problem. Extension of economic processes on the basis of international cooperation of Ukrainian enterprises leads to an ever bigger number of such agents of the global and national market as transnational corporations (TNS). The problem of research and application of transfer price formation, which is one of the most important management instruments in the structure of separate enterprises operating in different countries, deserves special attention in the development of such international relations. The main problem of transfer price formation is the policy of reasonable price setting, which has a direct influence on the amount of profit from the seller to the buyer. Therefore, the selection of transfer price formation method should meet certain selection criteria. The rules of transfer price formation in Ukraine are determined by the Law of Ukraine "On Amendments to the Tax Code of Ukraine on Transfer Price Formation" No. 609VIII of 15.07.2015 [20] and the Tax Code of Ukraine [19]. However, taking into account a relatively recent time of legislative establishment of transfer price formation rules, a sustainable practice of their application has not been developed yet, and, therefore, there is no single methodology for determination of the method of transfer price formation in a controlled transaction.

Analysis of the recent research and publications. The foundations of transfer price formation in economic theory and practice were laid by the famous German researcher
E. Schmalenbach in 1903 [1]. The method of transfer price formation is in the focus of attention of international researchers, such as A. Wagenhofer [2], J. Dearden [3], C. Drury [4], H. Kupper [5], D. Pfaff, U. Stefani [6], W. Schön, K. A. Konrad [7], M. Baro [8], R. Moller [9], J. Wrappe, M. Levey [10], Ch. Horngren [11] and others. Ukrainian authors writing on the issues of transfer price formation and focusing on comparison of its methods are: M. Romaniuk [12], T. Savchenko, M. Makarenko [13], O. Kotliarevskyi, V. Onishchenko [14], O. Tereshchenko [15], L. Napadovska [16], T. Karpova [17], V. Len [18] and others. Still, considering the great extent of research into transfer price formation and improvement of the regulatory system by the state, the issue of practical application remains important and topical for Ukrainian enterprises.

The purpose of the article is to highlight the peculiarities and practical application of the tranfer price formation methods at Ukrainian enterprises, their law and statutory regulation, and to determine main advantages and disadvantages of their application.

Presentation of basic material of the research. Intensification of international business in Ukrainian economy, as well as stabilization of the national economy by means of state regulation, is manifested in the necessity to develop and improve the mechanism of transfer price formation. To avoid capital flow from the country and to ensure proper tax payment, as well as improve the efficiency of the tax system and control over transfer prices, Ukraine adopted the Law of Ukraine "On Transfer Price Formation" and amended the Tax Code of Ukraine. These legislative acts on transfer price formation are based on the international experience of practical application of transfer price formation method, the main standard of control being the "long arm principle". This principle is based on the state 


\section{A. Yasinska}

control through its tax authorities over transfer pricing by adjusting tax liabilities of the taxpayers. In Ukrainian tax legislation, the "long arm principle" is formalized in article 39 of the Tax Code of Ukraine, which stipulates that the tax control over transfer pricing envisages adjustment of tax liability of a tax payer calculated on condition of correspondence of commercial and financial conditions of a controlled transaction to commercial and financial conditions that existed at the moment of conducting comparative transactions stipulated by this article, the parties to which are unrelated persons. Article 39 "Transfer price formation" of the Tax Code of Ukraine [19] determines the rules of setting regular prices of goods (works, services) in controlled transactions, the total amount of which equals or exceeds 50 million UAH (less VAT) for a respective calendar year. To determine the price, as well as to control transfer price formation of controlled transactions, the following methods are stipulated: comparative uncontrollable price (comparable sales); resale prices; "costs plus"; profit distribution; net profit. These methods are described in Table 1.

Table 1

Characteristics of the transfer price formation methods according to the TCU [19]

\begin{tabular}{|l|l|}
\hline \multicolumn{2}{|c|}{ Methods } \\
$\begin{array}{l}\text { Comparative } \\
\text { uncontrollable price } \\
\text { (comparable sales) }\end{array}$ & $\begin{array}{l}\text { is a comparison of the price applied during a controlled transaction with the price in } \\
\text { compared uncontrollable transaction(s), which were actually performed by the taxpayer } \\
\text { (other persons), or on the basis of the information about prices applied during the analyzed } \\
\text { period, particularly the information about the prices on the day closest to the date of the } \\
\text { controlled transactions (article 39 par. 39.3.3.1, par. 39.3.3.3) }\end{array}$ \\
\hline Resale prices & $\begin{array}{l}\text { is a comparison of the gross profit margin from resale of goods (works, services) } \\
\text { purchased in a controlled transaction with a gross profit margin from resale of goods } \\
\text { (works, services) received from comparative uncontrollable transactions (article 39 } \\
\text { par. 39.3.4.1) }\end{array}$ \\
\hline Cost plus & $\begin{array}{l}\text { is a comparison of the gross margin of the self cost of selling goods (works, } \\
\text { services) in a controlled transaction with a similar indicator of cost effectiveness in } \\
\text { comparative uncontrollable transactions (article 39 par. 39.3.5.1) }\end{array}$ \\
\hline Profit distribution & $\begin{array}{l}\text { is allocation of a part of the general profit (or loss) received as a result of controlled } \\
\text { transaction(s) to each person participating in such controlled transaction(s); this part } \\
\text { of the general profit (or loss) is equal to the one an unrelated person would receive } \\
\text { as a result of a comparative uncontrollable transaction(s) (article 39 cc. 39.3.7.1) }\end{array}$ \\
\hline Net profit & $\begin{array}{l}\text { is a comparison of the respective financial indicator of cost effectiveness in a } \\
\text { controlled transaction (net profit on the respective basis (costs, sales, assets) or the } \\
\text { indicator of operating costs effectiveness) with the respective cost effectiveness } \\
\text { indicator in comparative uncontrollable translation(s) (article 39 par. 39.3.6.1) }\end{array}$ \\
\hline
\end{tabular}

Ukrainian tax legislation (the Tax Code of Ukraine) and rules of the Organization for Economic Cooperation and Development (OECD) determine the rules of application of the transfer price formation methods. In selection of a certain method of setting the transfer price in a controlled transaction, the main criterion is the feasibility of adjustment, which is done to ensure comparability of controlled transactions. It is allowed to use two and more methods which a company may deem acceptable and grounded at its discretion. However, if there is a possibility to apply the method of comparative uncontrollable price (comparable sales), it is given preference over the others. Practical application of this method is complicated due to the lack of statistical information for determination of prices during the controlled transaction, which is necessary to compare market prices of similar goods (works, services) in comparative transactions. The information on market prices used is taken from the generally available official sources, like the State Information and Analytics Center for Monitoring International Commodity Markets, the Agricultural Stock Exchange, official publication of the State Fiscal Service of Ukraine and others over a certain period of time. However, in fact, market prices may change every day, therefore such data become obsolete and make it impossible to compare prices in controlled transactions and comparative 
transactions, as it is required by the Tax Code of Ukraine. In practice, conditions of transaction performance include also the scope of sales, the currency of payment etc., and these conditions should be identical, i.e. to be such that do not make a significant influence on financial result. Fulfillment of all abovementioned conditions to determine the market price in controlled transactions using the comparative uncontrollable price method is complicated and, usually, one of the mentioned conditions is violated.

The method most widely used to analyze the cost efficiency of intermediaries with limited risk and to determine the price in regard to transactions in which goods are purchased from a related person and then resold to unrelated persons without significant modification of the goods is called the resale method. However, taking into account the conditions of application of this method, it is possible to state that there are certain obstacles to its application, particularly, the difference of the gross profit margin indicators of the selected companies and gross profit margin of the taxpayer, which is caused by differences in accounting policy of the companies. Some costs, such as transportation, warranty maintenance, insurance and others can be included in the current period costs or into the self-costs of goods. The discounts given can also be considered as either decrease of profit or as a part of sales costs. Such discrepancies can significantly influence the gross profit margin of a company. Meanwhile, specialized commercial databases do not contain any information on accounting policies of the companies, which could allow for making the appropriate adjustments and ensuring comparability of the gross profit margin indicators of the selected companies with the similar indicator of the taxpayer. Considering the abovementioned, application of this method using the gross profit margin indicators of comparable companies is not possible. It is possible to claim in this case that the accounting policy in controlled and uncontrolled transactions is the same and does not influence the gross profit margin of the transaction.

Determination of the price using the cost plus method is possible if certain conditions are fulfilled, in particular: performance of works, provision of services between two related persons; sale of goods, raw materials or semi-finished products under the agreements between related persons; sale of goods (works, services) under long- term agreements between related persons. This method focuses on assessment of the gross profit margin and thus its application has the same limitations as the resale price method (adjustment of costs does not seem possible). Correspondently, the cost plus method cannot be applied in case of absence of internal transactions. In practice, this method is often applied to transactions of selling goods by the producer to the distributor in case when the producer sells the comparable products to the address of the related distributor and independent distributing companies under the same conditions. Thus, the cost plus method may be used for analysis of prices in controlled transactions in case there are available internal comparable transactions.

Net profit method is considered to be universal and most applied in comparison to other methods. The idea of the method is to compare the indicators of net margin, which is achieved by a taxpayer in a controlled transaction, with market range of values of net margin of independent companies achieved by them in comparable transactions. The universality of this method lies in the fact that the operation profit (loss) indicator usually reflects financial results of operational activity to the fullest extent. In addition, this indicator considers as much as possible the possible differences of accounting policies of the examined company and the comparable companies. The net profit method is used when there are no or too little information on the basis of which it would be possible to make grounded conclusions concerning the sufficient extent of compatibility of commercial and financial conditions of the controlled and comparable transactions using other methods. The main goal of a taxpayer when using this method is to find independent companies with comparable functional profile involved into similar activity on comparable market. The TCU [19] envisages a number of cost-effectiveness indicators, which should be used proceeding from the peculiarities of the company and the character of the transaction itself. Therefore, it is possible to conclude that the net profit method is most suitable for analysis of a controlled transaction in regard to its fulfillment of the "long arm principle".

Profit distribution method is the least applied method in global and Ukrainian practice of analyzing transfer price formation. This method is used by the taxpayers when the controlled transaction is so much interconnected with other 


\section{A. Yasinska}

transactions performed by the same parties that it is not possible to determine its contribution to the cumulative profitability of the parties. The method of profit distribution is also applied when both parties own intangible assets that have a significant influence on price formation. A sample situation when the application of this method would be appropriate could be joint production of any hightech product by several companies. Usually, the companies use this method when none of the abovementioned methods is applicable.

Having studied the issue of evaluating the transfer price formation methods it is possible to claim that in many cases application of the much preferred method of transfer price formation, that of comparative uncontrollable price, is impossible due to the lack of necessary information, including delivery conditions, specifications, exact delivery dates and other characteristics in generally available sources. The conditions of using the resale price method and cost plus method in the part of reflection of costs in the accounting policy of the compared companies are under researched. Due to such limitations of the methods as lack of key features of the goods in generally available sources, imperfection of the financial information databases, differences in accounting policies of the compared companies, and others, the taxpayers may use the wrong method and, consequently, pay their taxes incorrectly, which is a great risk both for an enterprise registered in Ukraine, and for the group as a whole.

Thus, research into the methods of transfer price formation, determination of their advantages and disadvantages, and ways of their elimination is quite topical. Table 2 presents the main advantages and disadvantages of each of the methods of transfer price formation.

Advantages and disadvantages of the transfer price formation methods

Table 2

\begin{tabular}{|c|c|c|}
\hline Methods & Advantages & Disadvantages \\
\hline $\begin{array}{l}\text { Comparative } \\
\text { uncontrollable price } \\
\text { (comparable sales) }\end{array}$ & is preferred over other methods & $\begin{array}{l}\text { lack of statistical information for the method } \\
\text { to be used; } \\
\text { is used for analysis of internal and external } \\
\text { uncontrollable price; } \\
\text { conditions of transactions should be } \\
\text { comparable and not make significant impact } \\
\text { on financial result; } \\
\text { impossible to apply for determination of the } \\
\text { market price of a controlled transaction }\end{array}$ \\
\hline Resale prices & $\begin{array}{l}\text { can be used for analysis of prices in a } \\
\text { controlled transaction provided there are } \\
\text { available internal comparable } \\
\text { transactions }\end{array}$ & $\begin{array}{l}\text { differences in indicators of gross margin of } \\
\text { companies and taxpayers; } \\
\text { the existing databases do not fully reflect the } \\
\text { information on gross margin indicators, thus } \\
\text { rendering their adjustment impossible; }\end{array}$ \\
\hline Cost plus & $\begin{array}{l}\text { allows the selling enterprise to receive } \\
\text { profit from transfer of its goods (services) }\end{array}$ & $\begin{array}{l}\text { cannot be applied if there are no internal } \\
\text { comparable transactions; } \\
\text { the existing databases do not fully reflect the } \\
\text { information on gross margin indicators, thus } \\
\text { rendering their adjustment impossible }\end{array}$ \\
\hline Profit distribution & $\begin{array}{l}\text { joint production of any high-tech } \\
\text { products by several companies; } \\
\text { both parties own intangible assets, whose } \\
\text { cost influences the price }\end{array}$ & $\begin{array}{l}\text { the least applied of all methods of transfer } \\
\text { price formation; } \\
\text { controlled transaction should be } \\
\text { interconnected with other transactions } \\
\text { performed by both parties; } \\
\text { it is complicated to determine the contribution of } \\
\text { every parties into the total return of both parties }\end{array}$ \\
\hline Net profit & $\begin{array}{l}\text { universality of application - the indicator } \\
\text { of operational profit (loss) fully reflects } \\
\text { the financial result of operational activity; } \\
\text { is most suitable for analysis of } \\
\text { compliance of the controlled transaction } \\
\text { with the "long arm principle" }\end{array}$ & $\begin{array}{l}\text { the necessity to search for independent } \\
\text { companies with comparable functional profile, } \\
\text { which are engaged into similar activity on a } \\
\text { comparable market }\end{array}$ \\
\hline
\end{tabular}




\section{Law and Statutory Regulation of Transfer Price Formation in Ukraine}

It is worth mentioning that consideration of advantages and disadvantages of each transfer price formation method will allow a company that belongs to a transnational group of companies to select the most reasonable method for analysis of prices and profitability indicators in controlled transactions. This will allow for avoidance of material and reputational risks for the company and the whole group of companies to which it belongs. The analysis of transfer price formation methods and peculiarities of their application revealed the necessity to improve these methods. Taking into consideration Ukrainian realities, the prioritized method of transfer price formation - the method of comparative uncontrollable price - requires most changes and specification in terms of possibility to use generally available sources of information for the purposes of transfer price formation.

\section{Conclusions and prospects for further} research. Application of transfer price formation methods at Ukrainian enterprises is considered in the following cases: for forming the methodology of setting the transfer price in order to neutralize conflicts of interests and improve internal economic financial relations; for manipulating transfer prices in order to decrease the tax burden and withdraw the capital from Ukraine. However, it is worth mentioning that the issues of choosing the acceptable methods of transfer price formation, grounding certain conditions of price formation, as well as avoiding conditions for double taxation and uncertainties, which could discourage direct foreign investments and hinder the development of foreign trade, remain relevant and require further research.

\section{References}

1. Schmalenbach E. Uber Verrechnungspreise / E. Schmalenbach // Zeitschrififurhandelsswissenschaftliche Forschung. 1909. Vol. 3. - No. 3. - S. 165-185.

2. Ewert $R$. Interne Unternehmensrechnung / R. Ewert, A. Wagenhofer. 6 Auft. - Berlin: Springer, 2005. - $760 \mathrm{~s}$.

3. Anthony R. Management Control Systems / R. Anthony, J. Dearden. - Irwin, IL, 1984.

4. Drury C. Management accounting for business: a textbook / C. Drury ; transl. from English. Moscow: YUNITI-DANA, 2003. - 655 p.

5. Kupper H. SystemederKosten- und Erlosrechnung / H. Kupper, M. Schweitzer. - 8, uberard. Auft. Munchen : Vahlen, 2003.
6. Pfaff D. Verrechnungspreiseiseinder Unternehmenspraxis / D. Pfaff, U. Stefani // I Controlling. - 2006. - No. 10. - S. 517-524.

7. Wolfgang Schön, Kai A. Konrad. Fundamentals of International Transfer Pricing in Law and Economics. // Wolfgang Schön, Kai A. Konrad. 2012. $-387 p$.

8. Marcelo Baro. International Business: a case of abusive transfer pricing // Marcelo Baro. - 2013. $258 \mathrm{p}$.

9. Raymonds Moller P. Transfer pricing rules and competing governments. Oxford econ. papers. N. S., Oxford, 2002. - Vol. 54. - No. 2. P. 230.

10. J. D. Wrappe, Steven C. Wrappe, J. D., Marc M. Levey. Transfer Pricing: Rules, Compliance and Controversy (Fourth Edition). // J. D. Wrappe, Steven C. Wrappe, J. D., Marc M. Levey - 2013. $415 \mathrm{p}$.

11. Horngren Ch. Management Accounting. 10th edition / transl. from English - Saint-Petersburg: Piter, 2005. - $1008 \mathrm{p}$.

12. Romaniuk M. V. Transfer price formation in the tax system of Ukraine // Global Tendencies and Prospects of Development of the Financial System of Ukraine. - 2013. - P. 15-17.

13. Makarenko M. I. System of Transfer Price Formation if Commercial Banks [monograph] // M. I. Makarenko, T. H. Savchenko. - Sumy : SHEI "UAB NBU", 2008. - 238 p.

14. Kotliarevskyi O. V., Onishchenko V. V. Selection of the optimum method of transfer price formation in a commercial bank in Ukraine // All-Ukrainian research and practice conference "innovative potential of the global science - 21 st century". [Electronic resource]. - Mode of access: http://nauka.zinet.info/9/kotlyarevsky.php.

15. Tereshchenko O. I. Transfer price formation as an instrument of controlling // Ukrainian Finance. 2007. - No. 5. - P. 127-136.

16. . Napadovska L. V. Management Accounting: manual for university students. - Kyiv: Knyha, 2004. - 544 p.

17. Karpova T. P. Management Accounting: manual for university students. - Moscow: Audit, UNITY, 1998. -350 p.

18. Len V. S. Management Accounting: manual for university students. - Kyiv : Znannia-Pres, 2003. $287 p$.

19. Tax Code of Ukraine of 02.12.2010 No. 2755-VI [Electronic resource]: - Mode of access: // zakon.rada.gov.ua/laws/show/2755-17.

20. The Law of Ukraine of 15.07.2015 No. 609-VIII "On Amendment of the Tax Code of Ukraine re Transfer Price Formation”. [Electronic resource] // The Verkhovna Rada of Ukraine: [web site].Mode of access: http://zakon5.rada.gov.ual laws/show/609-19. 